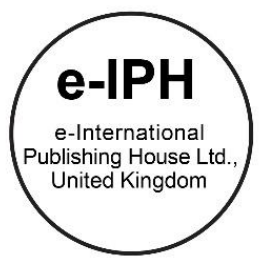

\title{
The Malay Enclave of Kampong Bharu as a Living Tradition: A place of uncertainty
}

\author{
Norsidah Ujang ${ }^{1 *}$, Faziawati Abdul Aziz² \\ ${ }^{1 *}$ Department of Landscape Architecture, Faculty of Design and Architecture, Universiti Putra Malaysia \\ ${ }^{1 * M I T-U T M}$ Sustainable Cities Program, Institute Sultan Iskandar, University Technology Malaysia \\ ${ }^{2}$ Department of Landscape Architecture, Faculty of Design and Architecture, Universiti Putra Malaysia
}

\begin{abstract}
In the case of Asian cities, poor redevelopment process has often resulted in the loss of historic urban fabric. Kampong Bharu is a traditional Malay settlement in the heart of the Kuala Lumpur city, holds a unique case of a struggle to preserve its local identity. This paper reviews the scenario regarding the enclave in light of the current redevelopment proposal. Reviews of literature and analysis of recent reports indicated that the future of the enclave is in the state of uncertainty. People oriented planning based upon a deep understanding of culture and tradition could bring about a natural approach towards a definitive redevelopment initiatives.
\end{abstract}

(c) 2016. The Authors. Published for AMER ABRA by e-International Publishing House, Ltd., UK. Peer-review under responsibility of AMER (Association of Malaysian Environment-Behaviour Researchers), ABRA (Association of Behavioural Researchers on Asians) and cE-Bs (Centre for Environment-Behaviour Studies), Faculty of Architecture, Planning \& Surveying, Universiti Teknologi MARA, Malaysia.

Keywords: Redevelopment, place identity, Malay ethnic enclave; Kampong Bharu

\section{Introduction}

Sustainable city agenda aims at improving the physical, environmental, social and economic qualities of cities to facilitate better social life. However, the uncontrolled development adversely affects the sustainability of cities, particularly the historic urban center. Poor gentrification process has often resulted in the loss of historic urban fabric and local identity (Shuhana, 2011). Therefore the sustainability and livability of, in particular, an ethnic enclave hinged on adapting to change and continuity of the cultural and physical character of the place (Bakri, et al., 2014). In the social context, the sustainable urbanism agenda advocates the concept of sustainable neighborhood and social benefits of development to the community (Oktay, 2012). This paper addresses the physical and social sustainability of Kampong Bharu, a Malay ethnic enclave located in the city center of Kuala Lumpur. Reviews from secondary resources provide this paper with contextual knowledge on Kampong Bharu with reference to the possibility of change in its built environment. The discussion is in light of the recently proposed redevelopment

\footnotetext{
* Corresponding author. Tel.: +06-012-302-9931; fax: +06-03-89480017.

E-mail address: norsidah@upm.edu.my
}

(c) 2016. The Authors. Published for AMER ABRA by e-International Publishing House, Ltd., UK. Peer-review under responsibility of AMER (Association of Malaysian Environment-Behaviour Researchers), ABRA (Association of Behavioural Researchers on Asians) and cE-Bs (Centre for Environment-Behaviour Studies), Faculty of Architecture, Planning \& Surveying, Universiti Teknologi MARA, Malaysia.

DOI: https.//doi.org/10.21834/e-bpj.v1i2.269 
initiated by the Kampong Bharu Development Corporation (KBDC) laid out in 2014. The objective of this paper is to review the existing approaches and strategies in redevelopment intervention of an ethnic enclave for future guide. The discussion will be limited to the case of the Malay Enclave of Kampong Bharu, the only remaining urban village in the heart of Kuala Lumpur city center. Issues related to the social sustainability and cultural identity will be the main focus of the discussion.

\section{Literature Review}

The approach of redevelopment within a traditional setting demands contextual consideration. As much as the transformation over time, the place is defined strongly by the social, cultural and religious contexts. The ethnic enclave, in particular was essentially "centers of meaning constructed out of lived experience" that would be perceived as significant to the lives of the people (Tuan, 1977). Insensitive intervention could diminish the familiar elements and meanings of places. As the condition affects the identity of the local urban places, there is a need to approach places contextually and understand the complexities of what give places their identities (Ujang and Zakariya, 2014).

\subsection{The social impact}

Urban redevelopment redefines places and communities. The impact of the intervention should be assessed based on how it will impact the place and the communities. It is to examine the consequences to human populations in terms of the ways in which people live, work, play, relate to one another, organize to meet their needs and cope as members of society. The impact may also include the cultural impacts involving changes to the norms, values, and beliefs that guide and rationalize their cognition of themselves and their society (http://unpan1.un.org). Based on the report published by Centre for Good Governance (2006), the development could socially impact the lifestyle (social interaction), cultural (custom and belief), community (social engagement and cohesion); quality of life (belonging, aspiration, perception); health (happiness and well-being). These factors lead to the questions on the implication of the proposed development to social identity? How will it benefit the society? At what level that the community will participate in the redevelopment process? These questions are relevant to Kampong Bharu for the place to transform naturally according to the need of time.

\section{Discussion}

\subsection{Kampong Bharu - a place of uncertainty}

Based on the historical information from The Malay Agricultural Settlement (MAS), Kampong Bharu was formed on January 12, 1900, by the Federated Malay States on the 223 acres land consisted of seven small villages and administered by the MAS Board of Management. The His Royal Highness the DYMM Sultan Abdul Samad, the Sultan of Selangor, awarded the land to the Malays from the Malay Archipelago, who held Islam as their official religion, converse in Malay and adopting the Malay culture. Those also include individuals who declared as 'Malay' by the M.A.S board of management. The purpose of the settlement formation was to encourage agriculture among the Malays, to take part in administrating the settlement and to involve in the business sector. The settlement had been under the British colonial rule, Japanese occupation and the period of independence. In the last ten years, Kampong Bharu (including the MAS area) has been the subject of speculation for real estate development. Despite the increasing need for urban improvement to avoid the dilapidated condition of the old buildings and to revive abandoned areas, the redevelopment plans by the related parties has been a futile effort.

\subsection{Redevelopment initiatives}

Kampong Bharu holds a unique case of a struggle to preserve local identity. Despite the initiatives by KBDC to facilitate development and to establish the resolution for redevelopment, the skepticism and resistance from the residents persist. The landowners were unwilling to undertake redevelopment due to land ownership, attitudes, physical planning, valuation and market constraints issues (Omar, et. al, 2006). The stalemate of the plans also relates to unclear redevelopment objectives, unfair compensation distribution and fear of the disappearance of Malay identity (Alhabshi, 2012). This situation raises the questions of 
how the current proposed development affects the local identity and socio-economic well-being of the residents in Kampong Bharu.

The Kuala Lumpur City Hall (KLCH) initiated the first development plan for Kampong Bharu in 1975. Not until the year 2008, the draft plan for Kuala Lumpur including Kampong Bharu was launched. However, the proposal did not materialize. The residents were unhappy with the plan because it was not focusing on preserving the settlement's identity and heritage and the land acquisition issue (Mustaffa, 2009). Currently, the 115-year-old 'kampong' remains 'underdeveloped', and the interested parties continue to face difficulty in transforming plans into reality. The initiative to redevelop the area was later resumed. A Comprehensive Development Master Plan was prepared by KBDC in 2014. The plan indicates a framework for future development of Kampong Bharu.

Change seems to inevitable for the enclave. What nature of change will suit the place and the inhabitants? The development of the Master Plan is in line with the vision for Kuala Lumpur to be a World Class City. The planning strategy for Kampong Bharu prevails in four integrated strategies: "holistic, inclusive and balanced planning, appreciation of the land value that is competitive, preservation of identity and heritage and green development for urban diversity" (KBDC, 2014). The aim is to improve the quality of life and the urban environment. In this regards, urban renewal should be aligned with the world class vision, expectations, and sustainability to achieve the development objectives (Alhabshi, 2012). Sustainability of a place could be determined as a result of an effective interrelation of three dimensions: the place (fact, identity, and behavior), the temporal (permanence, transformation) and the person (happiness, well-being, attachment) (Seghezzo, 2009). The traditional lifestyles of the enclave could be seen through community engagement and traditional and religious practices. Thus, any form of intervention should be culturally oriented and naturally embrace the aspirations of the inhabitants. Despite the difficulty in redeveloping the Malay Reservation Area (CHKL, 2004), such as the enclave, incremental steps in a form of a gradual process of transformation is deemed appropriate to the cultural context. What will be the future of Kampong Bharu? How could the recent plan benefit, the landowners and the residents, economically and socially? Hence, the proposed Master Plan should translate these issues effectively.

\subsection{Place identity}

The metropolitan Kuala Lumpur is a global city with modern character. In contrast, Kampong Bharu is a traditional setting; the last bastion against high-rise development in the Malaysian capital Kuala Lumpur (Gardland, 2014). These surrounding structures paradoxically emphasize the distinctiveness of the enclave. The traditional Malay and Islamic identities are reflected in the Malay traditional houses and religious buildings in the area. The KBDC Master Plan is inspired by the Malay and Islamic culture. The strategy to develop the area as a cultural hub that will benefit the residents is commendable. Incorporating the Malay heritage and Islamic identities the development is seen as an appropriate strategy. However, the sense of place lies deep in the history and the kampong life. Without correct translation of these elements, the land that has a unique pattern and the scale and intimacy of the kampong-ness will turn into another concrete jungle. The unique townscape qualities of the traditional street pattern and their adherence to human scale will be lost (Said, et.al, 2013).

An ethnic enclave is made up of both physical and cultural attributes, which gives its identity and sense of belonging. An enclave refers to as confined space occupied by groups of people by their ethnicity, the standard of living, religion, and sexual inclination (Bakri, et.al, 2014). The congregation of Malays in Kampong Bharu is obviously not by default but as a result of a premeditated colonial design (Alhabsi, 2012) and rooted under the grace of the Sultan. As Kuala Lumpur progress as a modern city, the natural need for change has transformed the original setting of the kampong into a more compact urban layout. In the1969, most of the high-rise buildings were concentrated in one side of Kampung Baru where else in 2004, high-rise buildings could have spread to other areas around the area (Hashim, et.al, 2011). Currently the kampongs are fully surrounded by highrise buildings including the iconic tower of Kuala Lumpur city center (KLCC) and high-density mixed-used development.

The landowners extended their houses for renting purposes while the mid-rise apartment buildings support the housing needs in the area. However, the character of the kampong remains despite the dilapidating condition of the old houses. The authenticity of the place as a traditional environment will be subdued if the local elements are not preserved and valued. Could the kampong retain its character in the growing interest of the stakeholders to redevelop the area in the name of economic progress? 

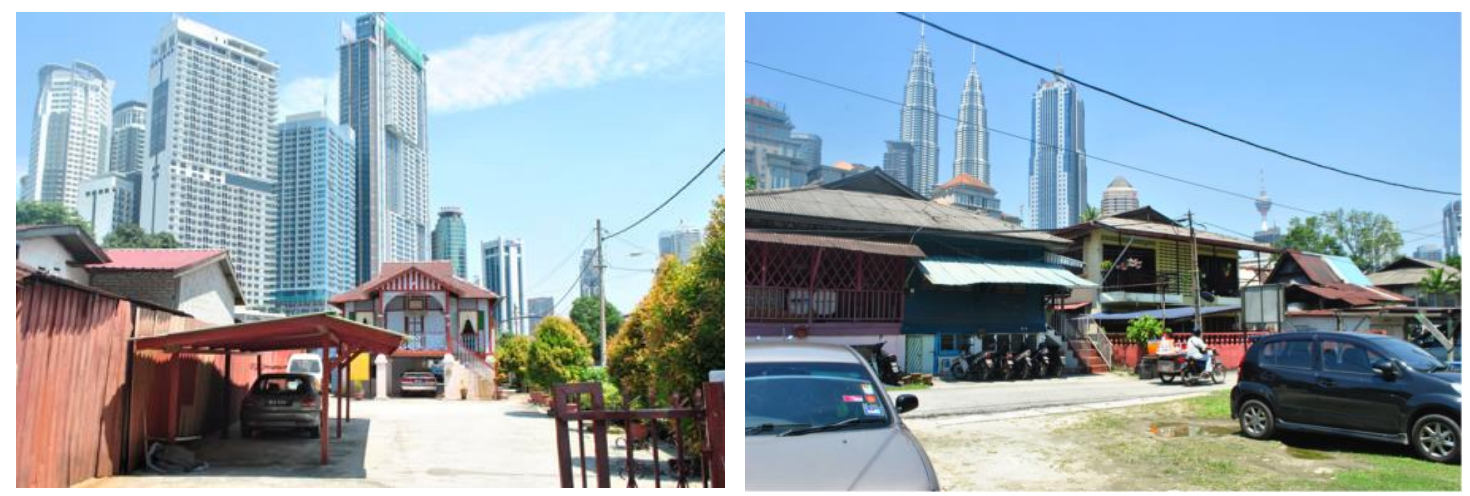

Fig.1 (a) View of a traditional house and its compound b) View of residence in Kampong Bharu

\subsection{The Malay Enclave as a social setting}

Kampong Bharu represents the Malay kampung physical and social environment. Fujita (2010) from Bunnell in "Kampung Rules," (p.1689) regarded "kampung" as a place of "traditional values, high morality, a space of resistance to the often alienating project of modernization, a space of community and support, neighborliness, and pride in one's community." These qualities reflect the unity of the Malays as social and political entities. The sense of place embedded in the people's attachment to the kampong environment and the formal and informal social group activities generate the sense of community and pride of collective identity. The continuing resistance to the redevelopment may indicate a strong sense of territorial belonging and ownership to the place. However, in later years, these values are challenged by the change in the lifestyle and means of social interaction. The traditional way of life continues to be practiced alongside the global culture. Will the people's attachment and territorial belonging remain steadfast despite the moving of the younger generations out from the area? Could the resistance to the proposed development come to a resolution appropriate to the needs and aspirations of the inhabitants? The residents' aspirations and visions of what should be the future of Kampong Bharu need to be brought to the forefront because the implications of the proposed redevelopment to the people's socio-economic well-being are at stake.

According to KBDC Master Plan, the kampong houses 18,000 population with the majority age range from 25-65 years (9624) while the number of older population is $682.72 .76 \%$ are Malay. 3.86 Chinese and $1.15 \%$ Indian while $2.18 \%$ are others. The Malay occupied the original Malay Agriculture Settlement. The Master Plan seeks to ensure holistic, inclusive and balanced planning in all aspects of sustainable planning that "gives positive impact to landowners, beneficiaries, and the current population, inhabitants and businesses in Kampong Bharu" (KBDC, 2014). In this regards, social equity and the social impact of the proposed development could be assessed in examining the potential change in the lifestyle and social interaction, sense of belonging and well being. The transaction along the smaller streets in Kampong Bharu may disappear bit by bit along with the emergence of high-rise and high-density building blocks. The way people engage with the spaces in a modern environment could be regarded as 'unfamiliar' if the spatial pattern has no reference to the traditional environment. Any planning and design intervention should consider the attachment of the existing users and avoid destroying the elements that are familiar and meaningful to them (Ujang, 2008).

Ghahramanpouri et.al. (2015) from Dixon (2012) highlights that social sustainability is translated in a socially cohesive and physically integrated urban unit, relating society and the individual and personal aspects of life. In the case of Kampong Bharu, the existing spatial structure allows for shared spaces among neighbors and informal transaction along the smaller streets. The setting generates the cohesiveness and informality found in the traditional Malay kampong. The charm of traditional kampong sustains the sense of place. Attachment to the community and religious practices may have influenced the sense of well-being of the residents living in an area.

However these characteristics are fragile, as stated by Fujita (2010), "the formalization of space and the market-savvy that will come with the redevelopment of Kampong Bharu will be accompanied with a palpable assault on the social-spatial character of the neighborhood." In agreement with the statement, and in light of CHKL's planning idea, the redevelopment of the enclave will be like other new centers in Malaysia. The uniqueness of the area could not be sustained because appreciation of what it 
was will be blinded by money- making real estate (Alhabshi, 2012). The floor area ratio at ten will restructure the informal and human-scaled pattern of the Malay kampong.

\subsection{The natural way forward}

KBDC has designed the framework for future development in the area. The Malay settlement is a living tradition that could be regarded a place of uncertainty. Changes bring about by the proposed Master Plan could transform the place according to the current demands. Unsuited development concept may eradicate the socio-cultural values of the community. The 'change' and transformation seems to be inevitable; while the real definition of change and transformation may vary according to the needs and reality. The continuity of place identity and social sustainability has a profound relationship with the culture, local ways of life, and human physical and psychological health. There is a need to redefine culture in the context of progressing Malay ethnic population. Interpretation of change and transformation has to be translated in the context of history, social-culture and human needs for identity and well-being. These frameworks may direct redevelopment initiatives more cohesively. The following describes the basis that is imperative in dealing with redevelopment of an enclave as historical and social settings:

- Understanding of people (who they are) and culture, way of life, needs and aspiration

- Redefining the social-cultural values according to the current reality

- The notion of progress goes beyond the physical manifestation of growth; human psychological well-being and psychological health also define progress and happiness

- Community values should be central to the sense of well-being

- Delineating change and transformation based on the physical, social-cultural and spiritual needs of the people and the community

- Understanding the meanings and values attached to the place and the sense of belonging; the attachment factors should indicate the significant elements that give meanings to life.

Planning should be based on profound cultural knowledge by acquiring an in-depth understanding of the particular culture (Mazumdar et.al, 2000). The dynamic of culture demands for a direct understanding of the existing people in place, their thoughts, experience, and perception. The sense of place in the context of the historical enclave of Kampong Bharu goes deeper into the history, the land and the ancestors/lineages that need to be respected.

\section{Conclusion}

The Malay traditional enclave of Kampong Bharu is a place of uncertainty. It could transform into a totally new modern center within the Kuala Lumpur metropolitan or development that intertwine the old and new where the historic character of the place sustains. The social and cultural values of the place could vanish if the new development ignores the understanding of the principles of life and belief system of the people who inhabit the area. The need and aspiration of the new generation dictate the face of the future development. The heritage values and the social cohesiveness defining the uniqueness of the place should not disappear alongside the emerging redevelopment. Social unity, social coherence, place identity and quality of life influence the people's well-being, therefore, should be equally emphasized in future redevelopment initiatives.

\section{Acknowledgement}

This paper is part of a sabbatical research work under the MIT-UTM Sustainable Cities Program. The Universiti Putra Malaysia has facilitated the preliminary part of the project under the Putra-IPB Grant.

\section{References}

Alhabshi, S. M. (2010). Urban renewal of traditional settlements in Singapore and Malaysia: The cases of Geylang Serai and Kampung Bharu. Asian Survey, 50(6), 1135-1161. 
Bakri, A. F., Zaman, N. Q., Kamarudin, H., \& Amin, N. M. (2014). Reviving the physical and cultural attributes of ethnic enclave: A conservation approach. Procedia-Social and Behavioral Sciences, 153, 341-348.

Center for Good Governance (2006). http://unpan1.un.org/intradoc/groups/public/documents/cgg/unpan026197.pdf. Retrieved on October 21, 2015.

CHKL, (2004). Kuala Lumpur Structure Plan 2020: A world class city.

Fujita, M. A. (2010). Forays into building identity: Kampung to kampong in the Kuala Lumpur Metropolitan Area. Journal of Architectural Education, $63(2), 8-24$. Gartland, A. (2014, February 3). Landowners in Malay enclave resist high-rise development. Retrieved October 16, 2015, from https://time2transcend.wordpress.com/

Ghahramanpouri, A., Abdullah, A. S., Sedaghatnia, S., \& Lamit, H. (2015). Urban social sustainability contributing factors in Kuala Lumpur Streets. ProcediaSocial and Behavioral Sciences, 201, 368-376.

Hashim N.R. and Mohd Yaacob, N. (2011). Urban landscape changes In Kampung Baru, Kuala Lumpur, from 1969 to 2004 as observed on maps. Journal of Design and Built Environment, Vol. 9, December 2011, pp. 49-58.

Ismail Omar, Hajjah Asiah Othman, Djurjani Wardata Pijono, Nugroho Djojomartono (2006). Strengthening the structure of development land market in Kampong Baru, Kuala Lumpur - Transaction cost of institutional economics analysis perspective, research report. RMC, UTM. http://eprints.utm.my/7857/1/74269.pdf. Retrieved on October 20, 2015.

KBDC (2014) Draft Development Master Plan of Kampong Bharu. http://www.pkb.gov.my/en/kampong-bharu-citizen/download, retrieved 11 Sept. 2015.

Mazumdar, S., Mazumdar, S., Docuyanan, F., \& McLaughlin, C. M. (2000). Creating a sense of place: the Vietnamese-Americans and Little Saigon. Journal of Environmental Psychology, 20(4), 319-333.

Mustaffa, R. (2009). "Development at the cost of identity loss?", streets, New Straits Times; Tuesday, 3 March, 2009.

Oktay, D. (2012). Human sustainable urbanism: In pursuit of ecological and social-cultural sustainability. Procedia-Social and Behavioral Sciences, 36, $16-27$.

Said, S. Y., Aksah, H., \& Ismail, E. D. (2013). Heritage conservation and regeneration of historic areas in Malaysia. Procedia-Social and Behavioral

Sciences, 105, 418-428.

Seghezzo, L. (2009). The five dimensions of sustainability. Environmental Politics, 18(4), 539-556.

Shuhana, S. (2011). Townscape revisited: Unraveling the character of the historic townscape in Malaysia. UTM Press.

Tuan, Y. F. (1977). Topophilia: A study of environmental perception, attitudes and values. New Jersey: Prentice-Hall Inc.

Ujang, N. (2008) Place attachment towards shopping district in Kuala Lumpur City Centre, PhD Thesis, Universiti Putra Malaysia.

Ujang, N., \& Zakariya, K. (2015). The notion of place, place meaning and identity in urban regeneration. Procedia-Social and Behavioral Sciences, $170,709-717$. 